\title{
Interface Characteristics and Bonding Performance of the Corrugated Mg/Al Clad Plate
}

\author{
Sha Li ${ }^{1,2}$, Xinyang Liu ${ }^{3}$, Yi Jia ${ }^{1,2}$, Jianchao Han ${ }^{1,2, *}$ and Tao Wang ${ }^{1,2, *}$ \\ 1 College of Mechanical and Vehicle Engineering, Taiyuan University of Technology, Taiyuan 030024, China; \\ tyutls@163.com (S.L.); tyutjiayi@163.com (Y.J.) \\ 2 Engineering Research Center of Advanced Metal Composites Forming Technology and Equipment, \\ Ministry of Education, Taiyuan 030024, China \\ 3 College of Materials Science and Engineering, Taiyuan University of Technology, Taiyuan 030024, China; \\ liuxinyang20201115@163.com \\ * Correspondence: hanjianchao@tyut.edu.cn (J.H.); tyutwt@163.com (T.W.); \\ Tel./Fax: +86-351-6014008 (J.H.); +86-351-6014008 (T.W.)
}

Citation: Li, S.; Liu, X.; Jia, Y.; Han, J.; Wang, T. Interface Characteristics and Bonding Performance of the Corrugated $\mathrm{Mg} / \mathrm{Al}$ Clad Plate. Materials 2021, 14, 4412. https:// doi.org/10.3390/ma14164412

Academic Editor: Sumantra Mandal

Received: 29 June 2021

Accepted: 4 August 2021

Published: 6 August 2021

Publisher's Note: MDPI stays neutral with regard to jurisdictional claims in published maps and institutional affiliations.

Copyright: (c) 2021 by the authors. Licensee MDPI, Basel, Switzerland. This article is an open access article distributed under the terms and conditions of the Creative Commons Attribution (CC BY) license (https:// creativecommons.org/licenses/by/ $4.0 /)$.

\begin{abstract}
In this paper, a corrugated $\mathrm{Mg} / \mathrm{Al}$ clad plate was successfully manufactured by an upper corrugated roller and a lower flat roller at $400{ }^{\circ} \mathrm{C}$ rolling temperature and $35 \%$ reduction ratio. Interface bonding performance of the corrugated $\mathrm{Mg} / \mathrm{Al}$ clad plate was studied by tensile-shear test. The finite element method was used to simulate the corrugated rolling process. Experiment results revealed that the $\mathrm{Mg} / \mathrm{Al}$ clad plate fabricated by corrugated roller had a tight bonding interface, no crack, and no intermetallic compounds. The transverse tensile-shear strength at the trough position reached $31.22 \mathrm{MPa}$, and the tensile-shear strength at the peak position was $17.61 \mathrm{MPa}$. It can be found that the stress and strain of interface metal at the trough position were the largest through numerical simulation results. Two cross-shear zones can be formed in the rolling deformation zone of the corrugated $\mathrm{Mg}$ / Al clad plate, which can accelerate the metal plastic flow and promote interface close bonding.
\end{abstract}

Keywords: $\mathrm{Mg}$ / Al clad plate; corrugated roller; interface bonding performance; numerical simulation

\section{Introduction}

With the rapid development of aerospace, electronic technology, petrochemical, and other emerging industries, it has been difficult to fulfill the comprehensive performance requirements of traditional single-metal material. Therefore, layered metal clad plates have attracted more and more attention [1-3]. A layered metal clad plate is a new material that can combine two or more metal plates through a specific preparation process. This kind of metal material has become a hot topic in recent years because of its simple preparation method, low cost, and high bonding strength $[4,5]$.

Metal Mg materials with lightweight, high specific strength, and high specific stiffness are widely used in aerospace, mechanical power, and other fields [6-8]. However, low corrosion potential, poor plastic deformability at room temperature, and other factors lead to the high production cost of $\mathrm{Mg}$, which greatly limit the wide use of $\mathrm{Mg}$ and its alloys [9-11]. Metal Al alloy is a light and environmentally friendly material with active chemical properties, which can easily react to oxygen in the air to form a dense oxide film. $\mathrm{Al}$ alloy has good corrosion resistance and plastic deformation ability, which is suitable for various forming methods [12,13]. Al and its alloys are widely used in transportation, marine vessels, artificial satellites, and other fields. Therefore, combining metal $\mathrm{Mg}$ and metal $\mathrm{Al}$ to make a $\mathrm{Mg} / \mathrm{Al}$ clad plate can give full play to the advantages of basic materials. $\mathrm{A} \mathrm{Mg} / \mathrm{Al}$ clad plate has a smaller density, higher strength, and good corrosion resistance [14,15].

At present, there are many methods to prepare $\mathrm{Mg} / \mathrm{Al}$ clad plates through the roller, such as hot-roll bonding, explosive + rolling, accumulative rolling, etc. Luo [16] realized the 
bonding of $\mathrm{Al} / \mathrm{Mg} / \mathrm{Al}$ three-layer clad plates by the two-pass hot-rolling method at $400{ }^{\circ} \mathrm{C}$. The results indicated that there was no intermetallic compound formed at the interface after the first rolling pass, but the intermetallic compound distributed at the interface in a discontinuous state after the second rolling pass. The author thought that the discontinuous intermetallic compound can limit crack propagation and consume the energy needed for crack propagation, improving the bonding strength of the clad plates. Chen [17] obtained the $\mathrm{Mg} / \mathrm{Al}$ clad plate through 5-pass hot-rolling after explosive welding, and the rolled $\mathrm{Mg} / \mathrm{Al}$ clad plates were annealed at different temperatures and holding times. The results revealed that the thickness of interface diffusion increased with annealing temperature and time, and the mechanical properties first increased and then decreased. Wu [18] prepared the $\mathrm{Mg} / \mathrm{Al}$ clad plate by accumulative rolling at $400{ }^{\circ} \mathrm{C}$. It was found that the tensile strength of the clad plate in the rolling direction and transverse direction decreased during the third cycle, which was due to the necking and cracking of the $\mathrm{Al}$ alloy plate.

In recent years, a new corrugated + flat rolling (CFR) process has been developed to prepare $\mathrm{Mg} / \mathrm{Al}$ clad plates. Some researchers have studied the $\mathrm{Mg} / \mathrm{Al}$ clad plate through the CFR technique. Wang [19] successfully prepared the $\mathrm{Mg} / \mathrm{Al}$ clad plate with a corrugated interface and flat surface by the CFR process, and the interface microstructure and mechanical properties were researched. $\mathrm{Li}$ [20] also produced the $\mathrm{Mg} / \mathrm{Al}$ clad plate by the CFR method. The result showed that there was no delamination at the interface and no crack at the base metals after the bending test. Wang [21] researched the interfacial microstructure of the $\mathrm{Mg} / \mathrm{Al}$ clad plate obtained only by the corrugated roller through the EBSD technology. The above-mentioned studies mainly analyze the CFRed $\mathrm{Mg} / \mathrm{Al}$ clad plate by experimental means, but few studies are carried out by numerical simulation. By simulating the rolling process of $\mathrm{Mg} / \mathrm{Al}$ clad plate with a corrugated roller, the parameters can be obtained, such as the change of stress and strain on the plate during the rolling process. Therefore, in this study, numerical simulation and experimental study are combined to study the interface characteristics and bonding performance of the corrugated $\mathrm{Mg} / \mathrm{Al}$ clad plate, and the relationship between stress and strain on the plate and the interface bonding performance is established.

\section{Experimental Method and Numerical Simulation}

\subsection{Experimental Method}

The original materials used in this study are AZ31B Mg alloy plate and $5052 \mathrm{Al}$ alloy plate. $\mathrm{Mg}$ plate and $\mathrm{Al}$ plate have the same size with length of $100 \mathrm{~mm}$, width of $60 \mathrm{~mm}$, and thickness of $2 \mathrm{~mm}$. The chemical composition and mechanical properties of the $\mathrm{Mg}$ plate and the Al plate used in the experiment are shown in Tables 1 and 2, respectively.

Table 1. Chemical compositions (in wt.\%) of AZ31B Mg plate and $5052 \mathrm{Al}$ plate.

\begin{tabular}{cccccccccc}
\hline Materials & $\mathbf{M g}$ & $\mathbf{C u}$ & $\mathbf{C a}$ & $\mathbf{M n}$ & $\mathbf{S i}$ & $\mathbf{A l}$ & $\mathbf{Z n}$ & $\mathbf{C r}$ & $\mathbf{F e}$ \\
\hline Mg plate & Rest & 0.01 & 0.04 & 0.8 & 0.07 & 3.2 & 1.2 & - & - \\
Al plate & $2.2-2.8$ & 0.1 & - & 0.1 & 0.25 & Rest & 0.1 & $0.15-0.35$ & 0.4 \\
\hline
\end{tabular}

Table 2. Mechanical properties of AZ31B Mg plate and $5052 \mathrm{Al}$ plate at room temperature.

\begin{tabular}{cccc}
\hline Materials & $\begin{array}{c}\text { Ultimate Tensile } \\
\text { Strength } \mathbf{( M P a )}\end{array}$ & Yield Strength (MPa) & Fracture Elongation (\%) \\
\hline Mg plate & 284 & 171 & 24 \\
Al plate & 217 & 135 & 18 \\
\hline
\end{tabular}

Before rolling, the metal surfaces to be bonded were ground with a wire brush until fresh metal was exposed. Then the polished surfaces were cleaned with alcohol to remove impurities such as oil stains. Finally, the polished plates were stacked to make the $\mathrm{Mg} / \mathrm{Al}$ plate blank. The prepared $\mathrm{Mg} / \mathrm{Al}$ plate blank was put into a tubular heating furnace with a preset temperature and argon protection for heat preservation treatment. The holding 
temperature was $400{ }^{\circ} \mathrm{C}$ and the holding time was $15 \mathrm{~min}$. In this rolling process, a rolling mill with upper corrugated roller and lower flat roller was used. The reduction ratio was set at 35\%. In the corrugated rolling process, the Mg alloy plate was in contact with the upper corrugated roller and the Al alloy plate was in contact with the lower flat roller. The experimental roller diameter is $150 \mathrm{~mm}$, and the surface curve of the corrugated roller is sinusoidal. After the rolling experiment, the corrugated $\mathrm{Mg} / \mathrm{Al}$ clad plate with corrugated $\mathrm{Mg}$ plate surface and microwave interface was obtained.

The interface morphology of the corrugated $\mathrm{Mg} / \mathrm{Al}$ clad plate was observed by scanning electron microscope (SEM, IT500) equipped with Energy Dispersive Spectrometer (EDS). Interfacial bonding strength of the corrugated $\mathrm{Mg} / \mathrm{Al}$ clad plate was tested by tensile-shear tests, and the sample was cut along the transverse direction (TD). The testing speed was $0.2 \mathrm{~mm} / \mathrm{min}$. After the mechanical tests, the fracture surfaces were observed and analyzed by SEM and EDS techniques. The surface roughness of interface metal after rolling was measured by three-dimensional profilometer.

\subsection{Numerical Simulation}

Using commercial finite element software ABAQUS 6.14-1 and temperature-displacement coupling dynamic explicit analysis method, the elastic-plastic solution of corrugated rolling process is realized. In this study, a two-dimensional rolling model is established. The initial temperature of the metal plate blank is set to $400{ }^{\circ} \mathrm{C}$ and the roller temperature is $20^{\circ} \mathrm{C}$. The initial thickness of the $\mathrm{Mg}$ plate and $\mathrm{Al}$ plate is $2 \mathrm{~mm}$. The numerical simulation process of rolling $\mathrm{Mg}$ / Al clad plate with corrugated roller involves the workpiece's large deformation process, which requires strict mesh division. The calculation amount is too large if the divided mesh is too small, and the calculation accuracy is not high if the divided mesh is too large. Therefore, ALE (Arbitral Lagrange-Euler) method will be used to solve this problem. The mesh generation is shown in Figure 1. To improve the calculation accuracy, plane strain four-node element CPE4RT is selected during the simulation process [22]. In addition, the reduction ratio is $35 \%$, which is the same as the actual rolling parameter.

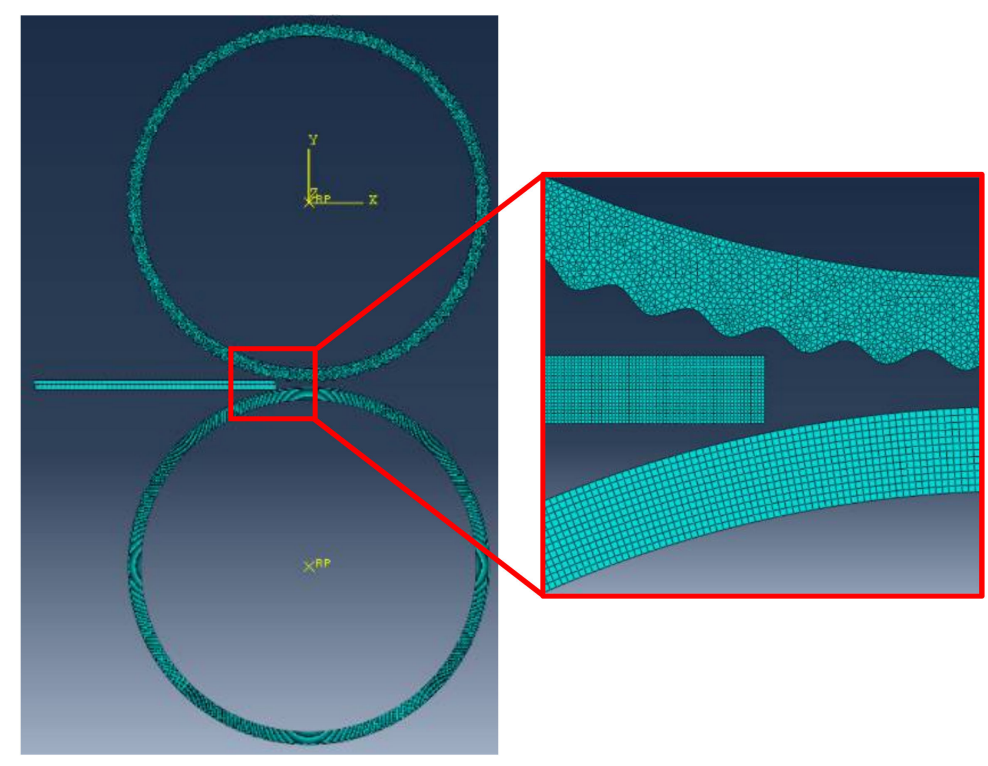

Figure 1. The meshing of the corrugated rolling process.

The rolling deformation zone of the corrugated $\mathrm{Mg} / \mathrm{Al}$ clad plate is divided into several small regions for subsequent analysis convenience, as shown in Figure 2. The deformation zone is divided into eight regions, i.e., Region 1 (R1), Region 2 (R2), etc. to Region 8 (R8), from the time when the corrugated roller just contacts with the upper $\mathrm{Mg}$ plate to the time when the rolled piece leaves the roller. 


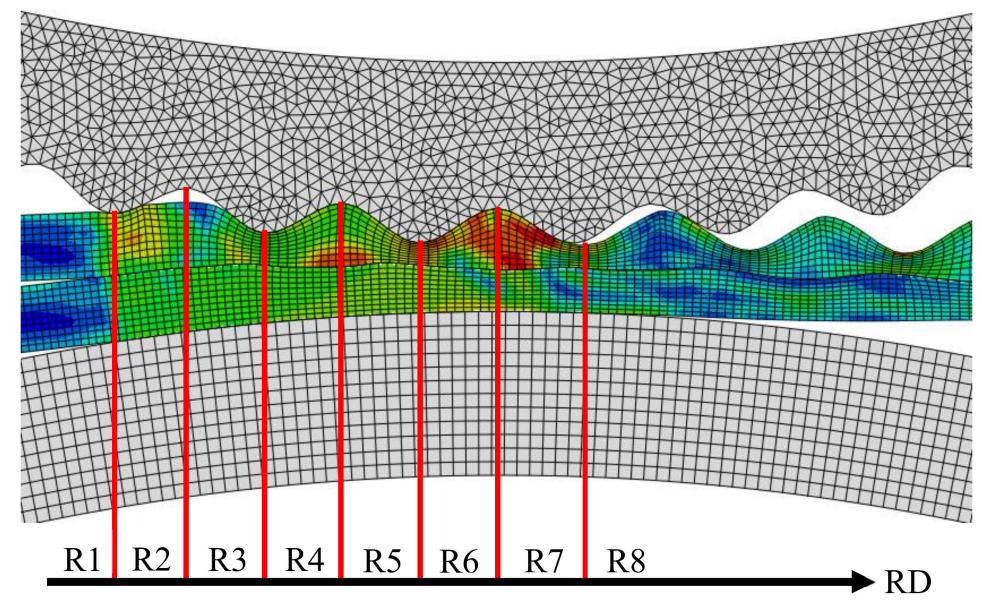

Figure 2. Zoning diagram of the corrugated rolling deformation zone.

\section{Results and Discussion}

\subsection{Interface Morphology of the Corrugated Mg/Al Clad Plate}

The corrugated $\mathrm{Mg} / \mathrm{Al}$ clad plate is prepared by the rolling mill with an upper corrugated roller and a lower flat roller under conditions of $400{ }^{\circ} \mathrm{C}$ temperature and $35 \%$ reduction ratio. Figure 3 displays the interface macro-morphology of the corrugated $\mathrm{Mg} / \mathrm{Al}$ clad plate. To facilitate follow-up research, four positions (front waist, peak, back waist, and trough) on the corrugated plate are defined according to the rolling direction and the $\mathrm{Mg}$ surface shape. The area where the metal $\mathrm{Mg}$ protrudes upward is called the peak position, and the area where the metal $\mathrm{Mg}$ sinks downward is called the trough position. The area before the peak position is called the front waist and the area after the peak position is called the back waist along the rolling direction. The specific positions are shown in Figure 3.

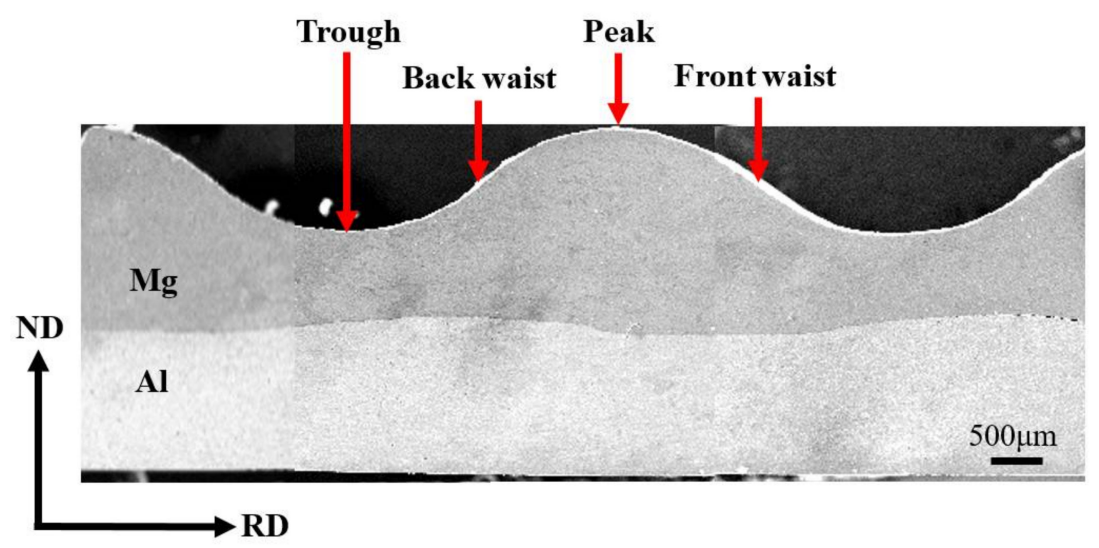

Figure 3. Interface macro-morphology and typical positions of the corrugated $\mathrm{Mg} / \mathrm{Al}$ clad plate.

Figure 4 shows the interface SEM images for the typical positions of the corrugated $\mathrm{Mg} / \mathrm{Al}$ clad plate and the corresponding line-scanning results. From Figure 4, it can be seen that the interfaces of the corrugated plate at the front waist, peak, back waist, and trough positions are well bonded, and there are no holes, cracks, and other defects at the interfaces. Meanwhile, the distribution of $\mathrm{Mg}$ element and $\mathrm{Al}$ element at the interface has a sudden drop according to the corresponding line-scanning results. The changing trend of elements shows $\mathrm{X}$ shape, which indicates that there is no stable hard brittle intermetallic compound layer at the interface. Although a stable intermetallic compound layer is not formed at the interface, the diffusion layer can be observed. It can also be seen from the line-scan diagram shown in Figure 4 that the thickness of the interface diffusion layer at four positions of corrugated $\mathrm{Mg} / \mathrm{Al}$ clad plate is different. The minimum thickness of the 
interface diffusion layer at the peak position is $4.2 \mu \mathrm{m}$, and the maximum diffusion layer thickness is $5.2 \mu \mathrm{m}$ at the trough position. The thickness of the interface diffusion layer at the front waist and the back waist positions is between the peak and trough positions. The interface diffusion layer thickness is different at these four positions, but the difference is not obvious.

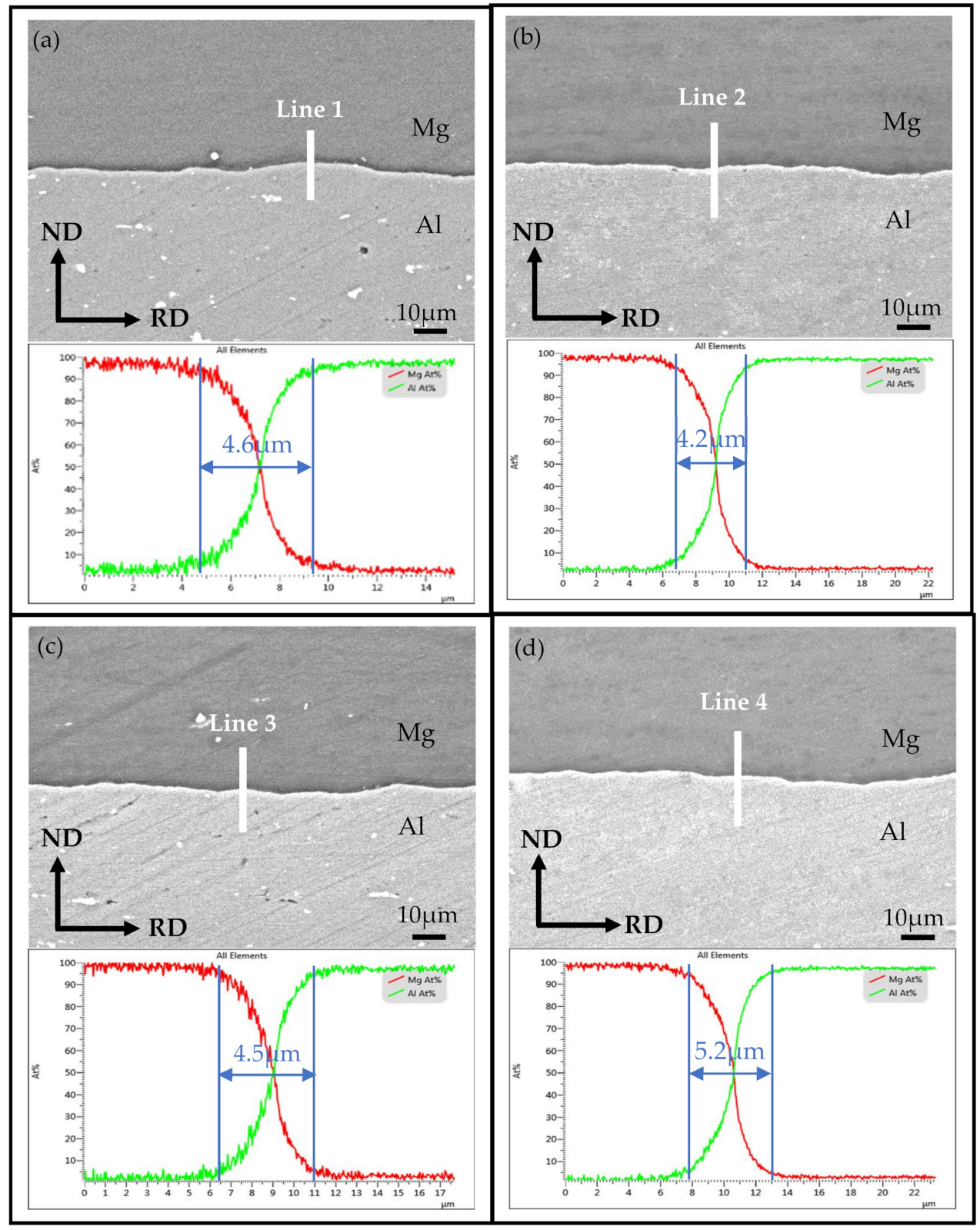

Figure 4. Interface SEM images and corresponding line-scan results of the corrugated $\mathrm{Mg} / \mathrm{Al}$ clad plate: (a) front waist, (b) peak, (c) back waist, (d) trough.

The surface roughness values of interfacial metal $\mathrm{Mg}$ and metal $\mathrm{Al}$ at four special positions after corrugated rolling are measured. Table 3 shows the metal surface roughness values. It can be seen from Table 3 that the roughness change trend is consistent with the thickness of the interface diffusion layer of the corrugated $\mathrm{Mg} / \mathrm{Al}$ clad plate. The larger the roughness value, the thicker the interface diffusion layer. Moreover, the larger rolling force can accelerate the surface fracture of the metal to be bonded and increase the metal roughness. The metal roughness value at the trough position $(\mathrm{Mg}$ of $3.597 \mu \mathrm{m}, \mathrm{Al}$ of $4.430 \mu \mathrm{m}$ ) is the highest, which can promote the interface element diffusion and improve the interface bonding quality of the clad plate. 
Table 3. Surface roughness of interface $\mathrm{Mg}$ plate and $\mathrm{Al}$ plate of the corrugated clad plate.

\begin{tabular}{ccccc}
\hline & Front Waist & Peak & Back Waist & Trough \\
\hline Mg plate & $3.205 \mu \mathrm{m}$ & $2.803 \mu \mathrm{m}$ & $3.121 \mu \mathrm{m}$ & $3.597 \mu \mathrm{m}$ \\
Al plate & $3.985 \mu \mathrm{m}$ & $3.157 \mu \mathrm{m}$ & $3.386 \mu \mathrm{m}$ & $4.430 \mu \mathrm{m}$ \\
\hline
\end{tabular}

\subsection{Effect of Stress and Strain on Interface Metal Deformation}

Figure 5 shows the normal stress distribution of the interface metals in the corrugated rolling deformation zone. Figure $5 \mathrm{a}$ is the normal stress nephogram, and Figure $5 \mathrm{~b}$ is the normal stress curve. It can be seen from Figure $5 b$ that the normal stress change trend of metal $\mathrm{Mg}$ and metal $\mathrm{Al}$ at the bonding interface is highly consistent, and the normal stress curves are almost coincident.
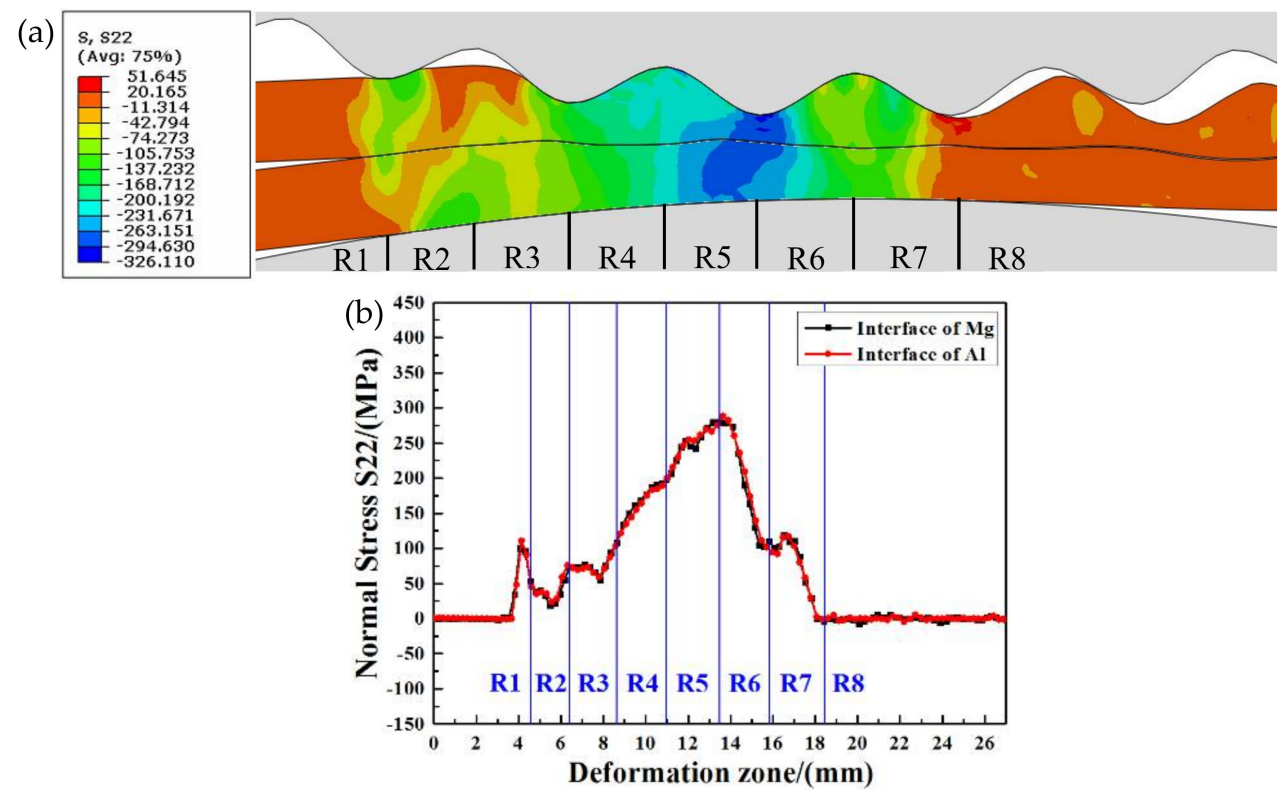

Figure 5. Normal stress distribution of interface metals in corrugated rolling deformation zone: (a) normal stress nephogram, (b) normal stress curves.

In the R1 region, the upper corrugated roller and the lower flat roller are in primary contact with metal $\mathrm{Mg}$ and metal $\mathrm{Al}$, respectively. Under the impact of the roller, the surfaces of $\mathrm{Mg}$ and $\mathrm{Al}$ are subjected to normal stress, and then the normal stress is transferred to the interface. At this time, the interface metals are suddenly subjected to the external force, and the normal stress increases and shows a linear growth trend. In the $\mathrm{R} 2$ region, the normal stress of $\mathrm{Mg}$ and $\mathrm{Al}$ decreases because the upper corrugated roller does not completely contact with the upper $\mathrm{Mg}$ plate. However, the normal stress of the interface metals in this R2 region is not completely reduced to zero, which is caused by the extrusion and pushing action of the roller in the R1 region to the metal in the R2 region. In addition, the normal stress of the metal near the R3 region rises slightly. The normal stress of interface metal fluctuates in the $\mathrm{R} 3$ region, and begins to rise near the $\mathrm{R} 4$ region until the normal stress in the R4 region continues to rise steadily. This is mainly attributed to the fact that the roller has been in complete contact with the metals since the R4 region, and the normal stress at the interface metal gradually increases as the rolling process continues. The normal stress at the interface metals reaches its peak at the junction of the R5 region and $\mathrm{R} 6$ region (279.6 MPa for $\mathrm{Mg}$ plate and $288.5 \mathrm{MPa}$ for Al plate). The rolled piece leaves the roller with the rolling process, and the normal stress begins to decrease until it drops to zero.

From Figure 5a, the junction of the R5 region and R6 region is the metal trough position, where the normal stress of the interface metal reaches the maximum value in the 
whole rolling deformation zone. It can be seen from Figure $5 b$ that the R5 region contains metal at the front waist of the plate, and the normal stress values of interface metal $\mathrm{Mg}$ and metal $\mathrm{Al}$ at the front waist are $245 \mathrm{MPa}$ and $253.6 \mathrm{MPa}$, respectively. The normal stress value is higher than that of metal $\mathrm{Mg}$ and metal $\mathrm{Al}$ at the back waist in the $\mathrm{R} 6$ region. The junction of the R6 region and R7 region is the metal peak position, where the normal stress of $\mathrm{Mg}$ and $\mathrm{Al}$ at the interface is $109.7 \mathrm{MPa}$ and $101.8 \mathrm{MPa}$, respectively. This normal stress value is the lowest among these four positions of the corrugated $\mathrm{Mg} / \mathrm{Al}$ clad plate.

Figure 6 shows the normal strain distribution of the interface metals in the corrugated rolling deformation zone. Figure $6 \mathrm{a}$ is the normal strain nephogram and Figure $6 \mathrm{~b}$ is the normal strain change curve. It can be seen from Figure $6 \mathrm{~b}$ that the shape of the normal strain curve of interface metals is corrugation, and the amplitude of metal Mg is larger than that of metal Al.
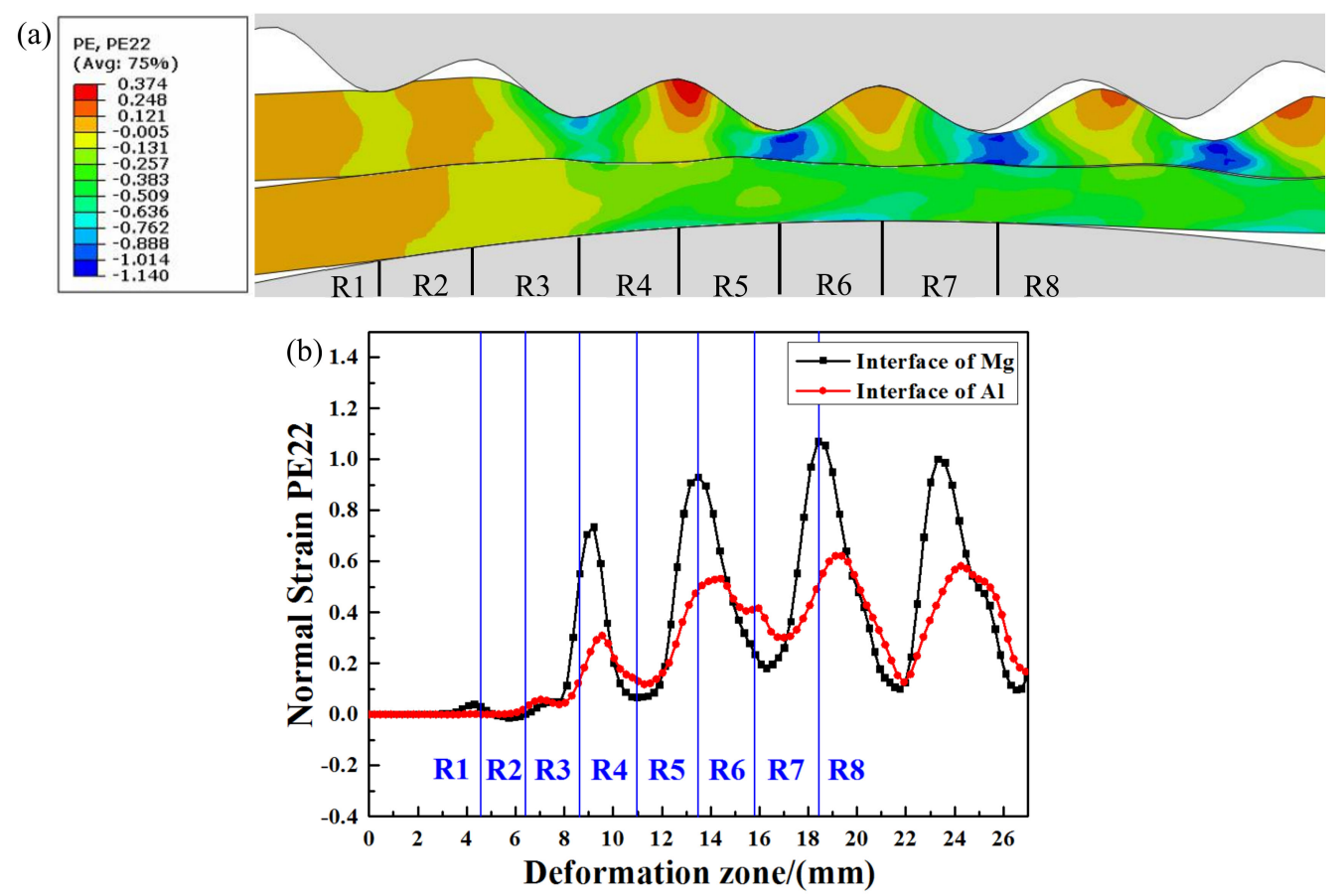

Figure 6. Normal strain distribution of interface metals in corrugated rolling deformation zone: (a) normal strain nephogram, (b) normal strain curves.

In the R1 region, the normal strain of metal Mg changes slightly, while the normal strain of metal $\mathrm{Al}$ is zero. The reason for this is that the $\mathrm{Mg}$ plate undergoes plastic deformation and transfer to the interface when the upper corrugated roller contacts with the metal $\mathrm{Mg}$, but there is no plastic deformation in metal $\mathrm{Al}$ at this time. In the R2 region, the normal strain of interfacial metals $\mathrm{Mg}$ and $\mathrm{Al}$ fluctuates, which is caused by the extrusion of the roller in the R1 region. At the junction of the R2 region and R3 region, the interfacial metal normal strain begins to rise synchronously and increase significantly in the $\mathrm{R} 3$ region. This is because the deformation occurs after the contact between the rollers and the plates, and the normal strain increases rapidly. In the $\mathrm{R} 4$ region, both $\mathrm{Mg}$ plate and $\mathrm{Al}$ plate reach the normal strain peak values ( 0.735 for $\mathrm{Mg}$ and 0.309 for $\mathrm{Al}$ ). Because the metals have not entered the stable rolling stage, the peak value of the normal strain of the interface metal does not appear at the junction of the R3 region and R4 region. As the rolling process continues, the upper corrugated roller contacts with the Mg plate at the back waist position, and the deformation of the $\mathrm{Mg}$ plate and $\mathrm{Al}$ plate decreases relative to the trough position. The normal strain of $\mathrm{Mg}$ and $\mathrm{Al}$ decreases until the peak position at the junction of R4 and R5. The interface normal strain of the Mg plate rises to the highest point (trough position) at the junction of the R5 region and $\mathrm{R} 6$ region ( $0.93 \mathrm{of} \mathrm{Mg}$ plate). 
However, the Al normal strain reaches the maximum value of 0.51 in the $\mathrm{R} 6$ region. This cycle is repeated until the $\mathrm{Mg} / \mathrm{Al}$ clad plate leaves the roller.

Although the changing trend of normal strain at the interface $\mathrm{Mg}$ and $\mathrm{Al}$ is consistent, the maximum value of the $\mathrm{Mg}$ normal strain is significantly higher than that of the $\mathrm{Al}$ plate. The peak value of the $\mathrm{Mg}$ normal strain is earlier than that of the $\mathrm{Al}$ plate. During the corrugated rolling process, the metal at different positions is subjected to uneven rolling force because of the special shape of the upper corrugated roller, resulting in various plastic deformation degrees of metal at different positions. The plastic deformation of metal $\mathrm{Mg}$ in direct contact with the corrugated roller is the largest at the trough position. However, because the deformation resistance of metal $\mathrm{Mg}$ and metal $\mathrm{Al}$ is different, and the plastic deformation degree of surface metal is greater than that of interface metal, the plastic deformation of metal $\mathrm{Mg}$ at the trough position does not penetrate metal Al. Therefore, the peak point of the metal $\mathrm{Mg}$ normal strain is higher than that of metal Al.

\subsection{Research of the Cross-Shear Zone}

Figure 7 shows the shear stress distribution of the $\mathrm{Mg}$ upper surface and the $\mathrm{Al}$ lower surface in the corrugated rolling deformation zone. Figure 7a is the shear stress variation nephogram and Figure $7 \mathrm{~b}$ is the shear stress variation curve. As can be seen from Figure 7b, the magnitude and direction of shear stress on the $\mathrm{Mg}$ upper surface change dramatically because of the direct action of the corrugated roller on the Mg plate.

(a)
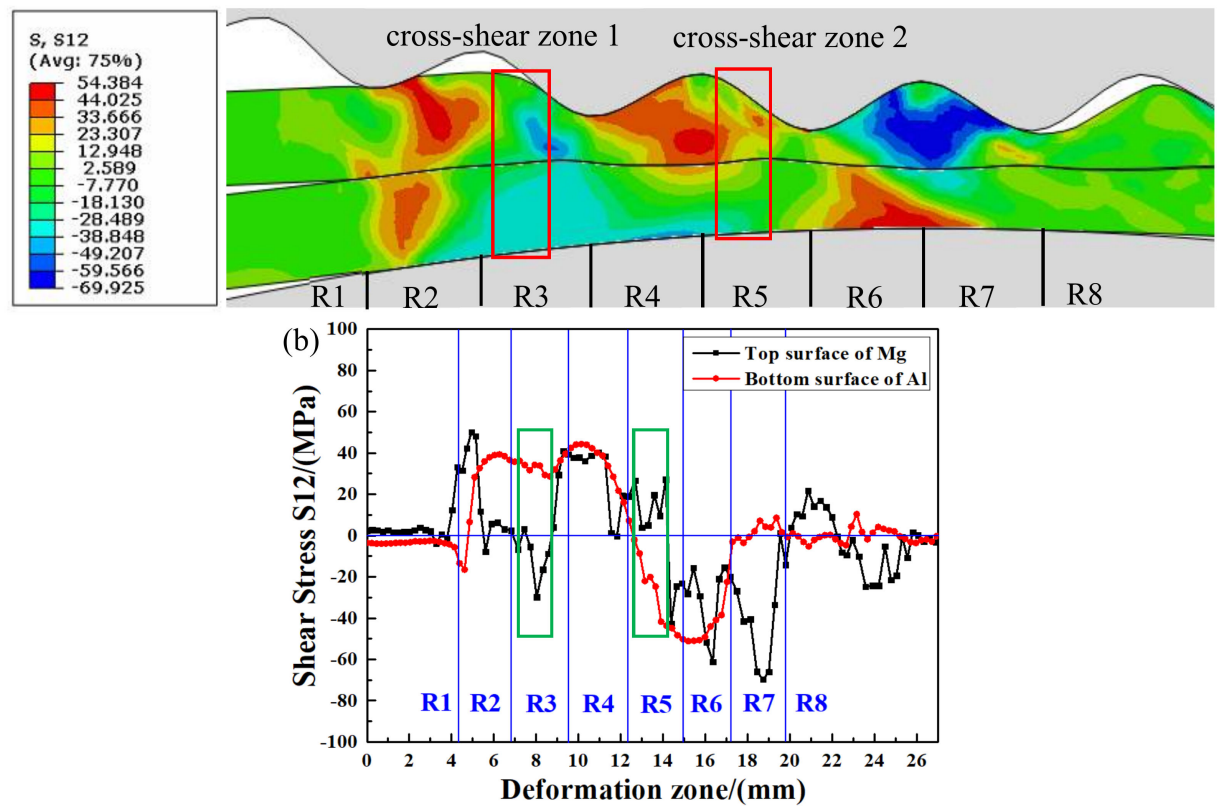

Figure 7. Shear stress nephogram of corrugated rolling deformation zone: (a) shear stress nephogram, (b) shear stress curves of the sheet surface.

In the R1 region, the shear stress on the Mg upper surface suddenly increases. When the outward protruding part of the corrugated roller is in contact with the Mg plate, it will have an impact on the plate, resulting in a sudden increase in the shear stress of the $\mathrm{Mg}$ plate. The first shear stress peak value on the Mg upper surface appears in region R2 due to the rubbing action of the roller, and the shear stress reaches $50.1 \mathrm{MPa}$. Because the $\mathrm{Mg}$ plate and the upper corrugated roller do not completely contact in the R2 region, the shear stress on the Mg upper surface drops to zero and then fluctuates slightly around zero. In the R3 region, the direction of shear stress on the $\mathrm{Mg}$ upper surface changes, which is opposite to the direction of shear stress on the Al lower surface. At this time, the cross-shear zone 1 is formed in the R3 region. It can be seen that the second peak value (29.8 MPa) of $\mathrm{Mg}$ plate shear stress appears in this cross-shear zone 1 (Figure 7b). In the R4 region, the direction of the $\mathrm{Mg}$ shear stress changes again and the shear stress value fluctuated steadily. 
In the R5 region, the shear stress direction on the Al lower surface changes. The shear stress directions of the $\mathrm{Mg}$ upper surface and the $\mathrm{Al}$ lower surface are opposite, forming cross-shear zone 2 in the R5 region. The junction of the R6 region and R7 region is the peak position of the Mg plate, so it shows a sudden drop of shear stress in the curve.

The cross-shear zones formed in the corrugated rolling deformation zone have been marked with rectangles in Figure $7 \mathrm{a}, \mathrm{b}$. In addition to the ordinary compression deformation, the metals in the cross-shear zone are also acted on by the additional shear deformation [23]. The existence of the cross-shear zones will accelerate the fracture of the hard brittle layer and the exposure of the fresh metal, improve the interfacial bonding strength [24]. For the $\mathrm{Mg} / \mathrm{Al}$ clad plate, there will be more slip systems of $\mathrm{Mg}$ plate in the cross-shear zone. The slip system type will also increase, and the deformation will be more severe. More sub-grains can be formed during severe plastic deformation, which can further promote the transformation of sub-grains to large-angle grain boundaries, thus completing the grain refinement process [25]. In addition, dynamic recrystallization is more likely to occur in $\mathrm{Mg}$ plate, which can also refine the grain and improve the $\mathrm{Mg}$ plate plastic deformation ability.

\subsection{Tensile-Shear Property}

The statistical diagram of transverse tensile-shear strength at four positions of the corrugated $\mathrm{Mg} / \mathrm{Al}$ clad plate is displayed in Figure 8. Tensile-shear strength can be calculated through $\tau_{b}=F / A$ [26], where $\tau_{b}$ is the strength, F is tensile-shear force, $A$ is the bonding area. It can be seen from Figure 8 that the tensile-shear strength at the trough position is the largest, $31.22 \mathrm{MPa}$, but the tensile-shear strength at the peak position is 17.61 MPa. The tensile-shear strength at the front waist $(25.21 \mathrm{MPa})$ and the back waist $(23.77 \mathrm{MPa})$ is in the middle, and the strength at the front waist is slightly higher than that at the back waist. From the previous simulation results, the stress and strain of metals at four typical positions of the corrugated $\mathrm{Mg} / \mathrm{Al}$ clad plate are different. The values of normal stress and normal strain on trough metals are the largest, while the values on peak metals are the smallest. The interfacial bonding strength of the clad plate is closely related to the fresh metal exposed on the metal surface to be bonded. The fresher the metal, the tighter the interfacial bonding strength. A large amount of fresh metal can be produced on the trough metal with large plastic deformation. These fresh metals will be squeeze into the other metal matrix to form a tightly bonded interface under the action of rolling force. However, the plastic deformation degree of peak metal is the smallest and a small amount of fresh metal is exposed, so the interface bonding strength at the peak position is the lowest.

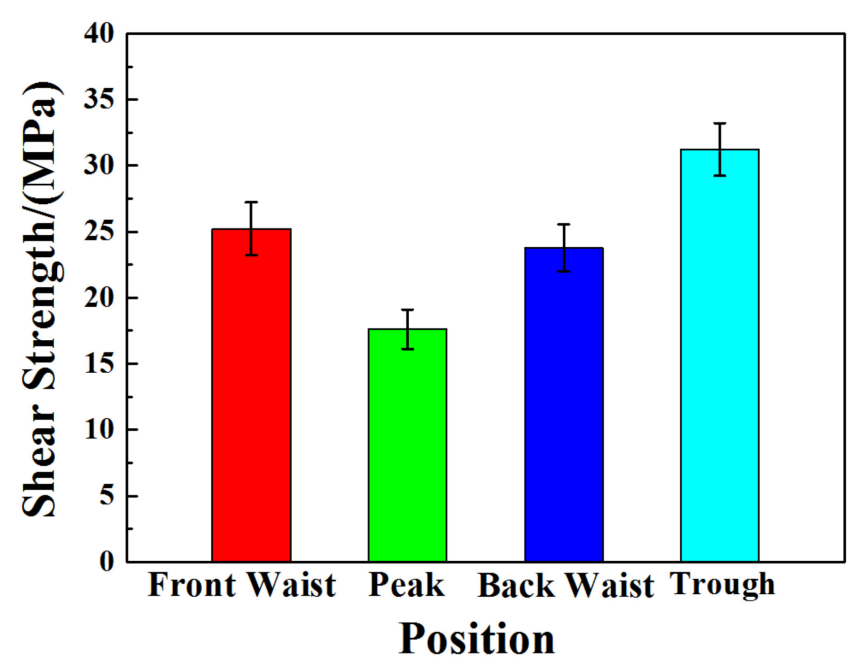

Figure 8. Transverse tensile-shear strength at four positions of the corrugated $\mathrm{Mg} / \mathrm{Al}$ clad plate.

Figure 9 is the fracture SEM images at the $\mathrm{Al}$ matrix side of the corrugated $\mathrm{Mg} / \mathrm{Al}$ clad plate after the tensile-shear test at four positions. It can be seen that the tearing ridges 
are contained on the Al matrix side at four positions, as shown in the yellow ellipses in Figure $9 \mathrm{a}-\mathrm{d}$. The metal $\mathrm{Mg}$ and metal $\mathrm{Al}$ are separated when the $\mathrm{Mg} / \mathrm{Al}$ clad plate is pulled. Mg alloys are firmly adhered to the Al matrix because of the tight bonding interface, and the tearing ridges are formed after the complete separation [27]. At the peak position (Figure 9b), the tearing ridges are short and a few. At the trough position (Figure 9d), an adhesive $\mathrm{Mg}$ lump can also be found on the side of the Al matrix in addition to the tearing ridges. This is mainly due to the high reduction ratio at the trough position. The metals are broken under the action of high rolling force to form cracks, and the fresh metal is extruded from these cracks and squeezed into the opposite matrix, thus forming a tight bond interface $[28,29]$. The number of tearing ridges at the front waist (Figure 9a) and the back waist (Figure 9c) is between the peak position and trough position.
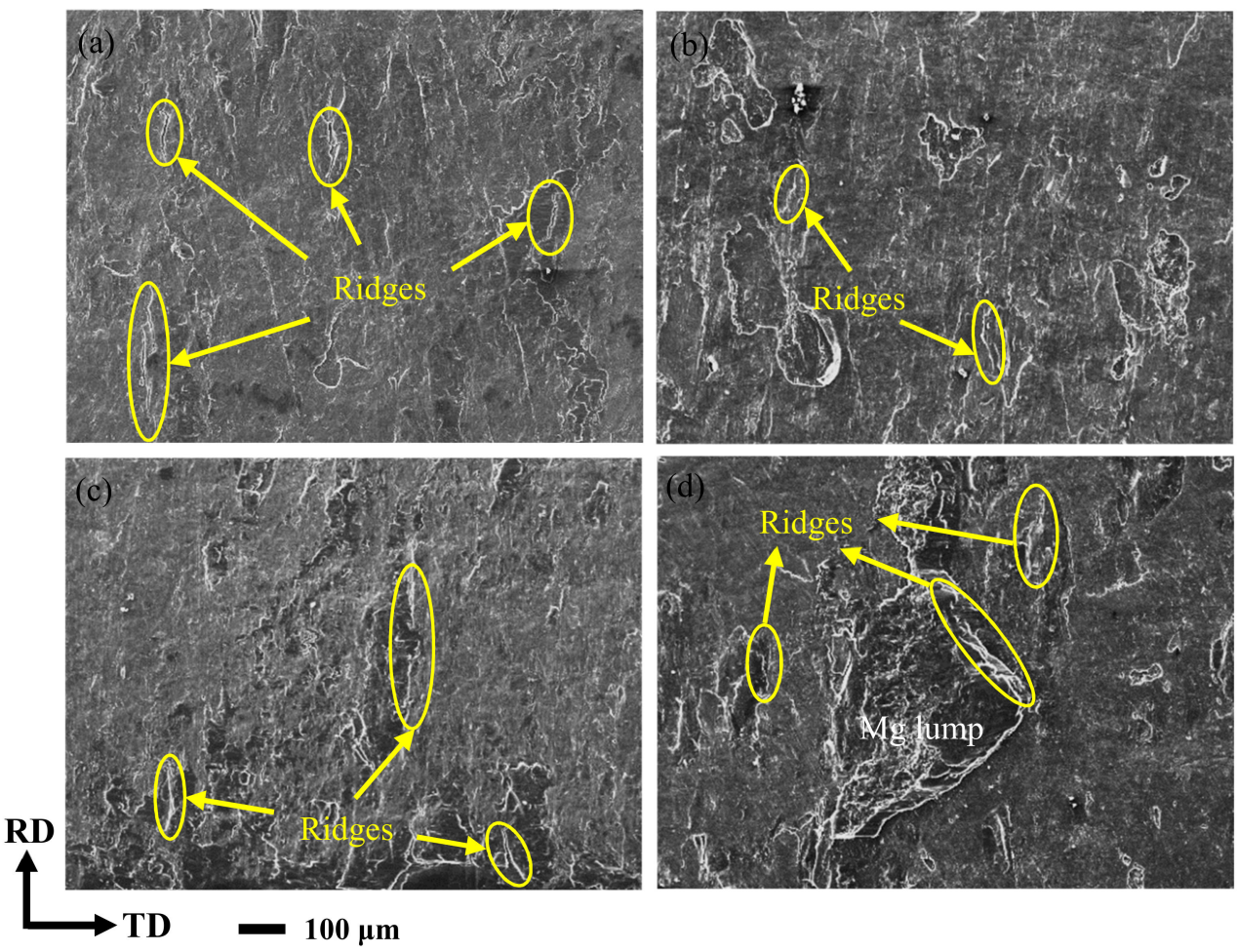

Figure 9. Tensile-shear fracture SEM images on the $\mathrm{Al}$-side of the corrugated $\mathrm{Mg} / \mathrm{Al}$ clad plate along the TD: (a) front waist, (b) peak, (c) back waist, (d) trough.

Figure 10 shows the surface-scan distribution at the fracture surface of the corrugated $\mathrm{Mg} / \mathrm{Al}$ clad plate after the tensile-shear test at four positions. In the surface-scan images, green represents the $\mathrm{Al}$ matrix metal, and red represents the metal $\mathrm{Mg}$ adhered to the $\mathrm{Al}$ matrix. The adhesion amount of metal $\mathrm{Mg}$ on the $\mathrm{Al}$ matrix at four positions is counted, and the statistical results are shown in Table 4 . It can be seen from Table 4 that in the Al matrix, the position of $\mathrm{Mg}$ adhesion from more to less is trough-front waist-back waist-peak, which exactly corresponds to the transverse tensile-shear strength of the corrugated $\mathrm{Mg} / \mathrm{Al}$ clad plate at four positions. This is largely due to the uneven stress distribution caused by the action of corrugated roller on the metals. It can also be seen from the scanning of tensileshear fracture surface in Figure 10 that a large Mg lump adheres to the Al substrate at trough position (Figure 10d). At the front waist position (Figure 10a) and back waist position (Figure 10c), the metal $\mathrm{Mg}$ adheres to the $\mathrm{Al}$ matrix in a strip discontinuous distribution along the rolling direction. Although the adhesion of metal $\mathrm{Mg}$ can also be observed at the peak position (Figure 10b), the content is less, and the distribution is scattered and not concentrated. In addition, numerous dimples can be observed at the trough fracture surface after tearing of magnesium, which is also an important manifestation of the high bonding strength at the trough position. 

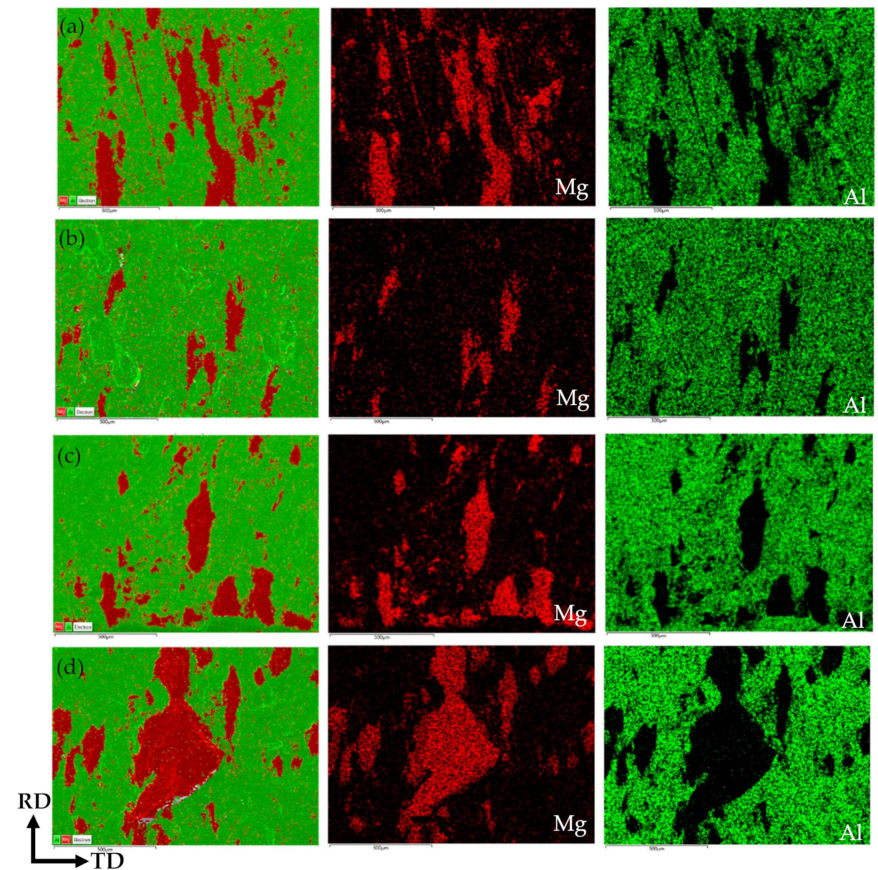

Figure 10. Element distribution of the transverse tensile-shear fractures on the Al-side of the corrugated $\mathrm{Mg} / \mathrm{Al}$ clad plate: (a) front waist, (b) peak, (c) back waist, (d) trough.

Table 4. The percentage of Mg element and Al element shown in Figure 10.

\begin{tabular}{ccc}
\hline Map Images & Mg (\%) & A1 (\%) \\
\hline (a)-Front waist & $22.46 \%$ & $77.54 \%$ \\
(b)-Peak & $8.29 \%$ & $91.71 \%$ \\
(c)-Back waist & $16.3 \%$ & $83.7 \%$ \\
(d)-Trough & $29.34 \%$ & $70.66 \%$ \\
\hline
\end{tabular}

\section{Conclusions}

Corrugated $\mathrm{Mg} / \mathrm{Al}$ clad plate was successfully manufactured by an upper corrugated roller and a lower flat roller at $400{ }^{\circ} \mathrm{C}$ rolling temperature and $35 \%$ reduction ratio. The interface bonding performance of the corrugated plate was studied by the tensile-shear test. The finite element method was used to simulate the corrugated rolling process, and the interface bonding performance difference of the corrugated plate was explained by analyzing the stress and strain distribution in the rolling deformation zone. The main conclusions are as follows:

After the corrugated rolling, the surface of $\mathrm{Mg}$ plate presents an obvious corrugation shape, and four typical positions (front waist, peak, back waist, and trough) are defined according to the rolling direction and the corrugation morphology. The corrugated $\mathrm{Mg} / \mathrm{Al}$ clad plate has a tight bonding interface, crack and intermetallic compound layer cannot be observed at the interface.

Corrugated $\mathrm{Mg} / \mathrm{Al}$ clad plate has excellent interfacial bonding strength. The transverse tensile-shear strength at the trough position reaches $31.22 \mathrm{MPa}$, and the tensile-shear strength at the peak position is $17.61 \mathrm{MPa}$, and the front waist and the back waist are located in the middle.

It can be found that the stress and strain of interface metal at the trough position are the largest through numerical simulation results. Two cross-shear zones are formed in the rolling deformation zone of $\mathrm{Mg} / \mathrm{Al}$ clad plate fabricated by corrugated roller, which can accelerate the metals plastic flow and promote interface close bonding. 
Author Contributions: Writing-Original Draft, S.L.; Software, X.L.; Formal Analysis, Y.J.; WritingReview and Editing, J.H.; Conceptualization, T.W. All authors have read and agreed to the published version of the manuscript.

Funding: This study is funded by National Natural Science Foundation of China (U1710254, 51904205, 51904206), Key Projects of Shanxi Province Key Research and Development Plan (201703D111003), China Postdoctoral Science Foundation (2018M641680, 2018M641681), and Natural Science Foundation of Shanxi Province (201801D221130, 201801D221339), The Central Government Guides the Special Fund Projects of Local Scientific and Technological Development (YDZX20191400002149).

Institutional Review Board Statement: Not applicable.

Informed Consent Statement: Not applicable.

Data Availability Statement: Not applicable.

Conflicts of Interest: The authors declare no conflict of interest.

\section{References}

1. Wasekar, N.P.; Latha, S.M.; Ramakrishna, M.; Rao, D.S.; Sundararajan, G. Pulsed electrodeposition and mechanical properties of Ni-W/SiC nano-composite coatings. Mater. Des. 2016, 112, 140-150. [CrossRef]

2. Chen, L.; Fu, Y.; Yin, F.; Liu, N.; Liang, C. Microstructure and Mechanical Properties of Mg/Al Clad Bars with Ni Interlayer Processed by Compound Castings and Multi-Pass Caliber Rolling. Metals 2018, 8, 704. [CrossRef]

3. Ahledel, N.; Schulz, R.; Gariepy, M.; Hermawan, H.; Alamdari, H. Electrochemical Corrosion Behavior of Fe3Al/TiC and Fe3Al-Cr/TiC Coatings Prepared by HVOF in NaCl Solution. Metals 2019, 9, 437. [CrossRef]

4. Tang, J.; Chen, L.; Zhao, G.; Zhang, C.; Yu, J. Study on Al/Mg/Al sheet fabricated by combination of porthole die co-extrusion and subsequent hot rolling. J. Alloy. Compd. 2019, 784, 727-738. [CrossRef]

5. Wachowski, M.; Kosturek, R.; Sniezek, L.; Mroz, S.; Stefanik, A.; Szota, P. The Effect of Post-Weld Hot-Rolling on the Properties of Explosively Welded Mg/Al/Ti Multilayer Composite. Materials 2020, 13, 1930. [CrossRef]

6. Qi, Z.C.; Yu, C.; Xiao, H. Microstructure and bonding properties of magnesium alloy AZ31/CP-Ti clad plates fabricated by rolling bonding. J. Manuf. Process. 2018, 32, 175-186. [CrossRef]

7. Nemcko, M.J.; Qiao, H.; Wu, P.D.; Wilkinson, D.S. Effects of void fraction on void growth and linkage in commercially pure magnesium. Acta. Mater. 2016, 113, 68-80. [CrossRef]

8. Yang, M.; Liu, X.B.; Zhang, Z.Y.; Song, Y.L. Stress Corrosion Behavior of AM50Gd Magnesium Alloy in Different Environments. Metals 2019, 9, 616. [CrossRef]

9. Liu, X.W.; Sun, J.K.; Zhou, F.Y.; Yang, Y.H.; Chang, R.C.; Qiu, K.J.; Pu, Z.J.; Li, L.; Zheng, Y.F. Micro-alloying with Mn in Zn-Mg alloy for future biodegradable metals application. Mater. Des. 2016, 94, 95-104. [CrossRef]

10. Jiang, M.G.; Yan, H.; Chen, R.S. Microstructure, texture and mechanical properties in an as-cast AZ61 Mg alloy during multidirectional impact forging and subsequent heat treatment. Mater. Des. 2015, 87, 891-900. [CrossRef]

11. Yan, Z.; Wang, D.; Wang, W.; Zhou, J.; He, X.; Dong, P.; Zhang, H.; Sun, L. Ratcheting Strain and Microstructure Evolution of AZ31B Magnesium Alloy under a Tensile-Tensile Cyclic Loading. Materials 2018, 11, 513. [CrossRef] [PubMed]

12. Mishra, R.R.; Sharma, A.K. On mechanism of in-situ microwave casting of aluminium alloy 7039 and cast microstructure. Mater Des. 2016, 112, 97-106. [CrossRef]

13. Simar, A.; Bréchet, Y.; de Meester, B.; Denquin, A.; Gallais, C.; Pardoen, T. Integrated modeling of friction stir welding of 6xxx series Al alloys: Process, microstructure and properties. Prog. Mater. Sci. 2012, 57, 95-183. [CrossRef]

14. Nie, H.H.; Liang, W.; Chen, H.S.; Zheng, L.W.; Chi, C.Z.; Li, X.R. Effect of annealing on the microstructures and mechanical properties of $\mathrm{Al} / \mathrm{Mg} / \mathrm{Al}$ laminates. Mater. Sci. Eng. 2018, 732, 6-13. [CrossRef]

15. Zhang, N.; Wang, W.X.; Cao, X.Q.; Wu, J.Q. The effect of annealing on the interface microstructure and mechanical characteristics of AZ31B/AA6061 composite plates fabricated by explosive welding. Mater. Des. 2015, 65, 1100-1109. [CrossRef]

16. Luo, C.Z.; Liang, W.; Chen, Z.Q.; Zhang, J.J.; Chi, C.Z.; Yang, F.Q. Effect of high temperature annealing and subsequent hot rolling on microstructural evolution at the bond-interface of $\mathrm{Al} / \mathrm{Mg} / \mathrm{Al}$ alloy laminated composites. Mater. Charact. 2013, 84, 34-40. [CrossRef]

17. Chen, Z.Q.; Wang, D.Y.; Cao, X.Q.; Yang, W.W.; Wang, W.X. Influence of multi-pass rolling and subsequent annealing on the interface microstructure and mechanical properties of the explosive welding Mg/Al composite plates. Mater. Sci. Eng. 2018, 723, 97-108. [CrossRef]

18. Wu, K.; Chang, H.; Maawad, E.; Gan, W.M.; Brokmeier, H.G.; Zheng, M.Y. Microstructure and mechanical properties of the $\mathrm{Mg} / \mathrm{Al}$ laminated composite fabricated by accumulative roll bonding (ARB). Mater. Sci. Eng. 2010, 527, 3073-3078. [CrossRef]

19. Wang, T.; Wang, Y.; Bian, L.; Huang, Q. Microstructural evolution and mechanical behavior of Mg/ Al laminated composite sheet by novel corrugated rolling and flat rolling. Mater. Sci. Eng. 2019, 765, 138318. [CrossRef]

20. Li, S.; Luo, C.; Bashir, M.-U.; Jia, Y.; Han, J.-C.; Wang, T. Interface structures and mechanical properties of corrugated + flat rolled and traditional rolled Mg/Al clad plates. Rare Met. 2021, 40, 2947-2955. [CrossRef] 
21. Wang, T.; Li, S.; Niu, H.; Luo, C.; Ma, X.; Liu, Y.; Han, J.; Bashir, M.U. EBSD research on the interfacial microstructure of the corrugated Mg/Al laminated material. J. Mater. Res. Technol. 2020, 9, 5840-5847. [CrossRef]

22. Wang, H.; Su, L.H.; Yu, H.L.; Lu, C.; Tieu, A.K.; Liu, Y.; Zhang, J. A new finite element model for multi-cycle accumulative roll-bonding process and experiment verification. Mater. Sci. Eng. 2018, 726, 93-101. [CrossRef]

23. Wang, T.; Li, S.; Ren, Z.; Han, J.; Huang, Q. A novel approach for preparing Cu/Al laminated composite based on corrugated roll. Mater. Lett. 2019, 234, 79-82. [CrossRef]

24. Wang, T.; Li, S.; Ren, Z.; Jia, Y.; Fu, W.; Guo, M.; Ma, X.; Han, J. Microstructure Characterization and Mechanical Property of $\mathrm{Mg} / \mathrm{Al}$ Laminated Composite Prepared by the Novel Approach: Corrugated + Flat Rolling (CFR). Metals 2019, 9, 690. [CrossRef]

25. Wang, T.; Liu, W.; Liu, Y.; Wang, Z.; Ignatov, A.V.; Huang, Q. Formation mechanism of dynamic multi-neutral points and cross shear zones in corrugated rolling of $\mathrm{Cu} / \mathrm{Al}$ laminated composite. J. Mater. Process. Tech. 2021, 295, 117157. [CrossRef]

26. Xiao, H.; Qi, Z.; Yu, C.; Xu, C. Preparation and properties for Ti/Al clad plates generated by differential temperature rolling. J. Mater. Process. Tech. 2017, 249, 285-290. [CrossRef]

27. Han, J.; Niu, H.; Li, S.; Ren, Z.; Jia, Y.; Wang, T.; Plokhikh, A.I.; Huang, Q. Effect of Mechanical Surface Treatment on the Bonding Mechanism and Properties of Cold-Rolled Cu/Al Clad Plate. Chin. J. Mech. Eng. 2020, 33, 69. [CrossRef]

28. Eizadjou, M.; Danesh Manesh, H.; Janghorban, K. Mechanism of warm and cold roll bonding of aluminum alloy strips. Mater. Des. 2009, 30, 4156-4161. [CrossRef]

29. Yousefi Mehr, V.; Toroghinejad, M.R.; Rezaeian, A. The effects of oxide film and annealing treatment on the bond strength of Al-Cu strips in cold roll bonding process. Mater. Des. 2014, 53, 174-181. [CrossRef] 